\title{
Intervention in Engineering Students’ Final Year Capstone Research Projects to Enhance Their Written, Oral and Presentation Skills
}

\author{
http://dx.doi.org/10.3991/ijep.v2i3.2107 \\ A. S. Blicblau, and K. Dini \\ Swinburne University of Technology, Hawthorn, Australia
}

\begin{abstract}
This article describes an intervention and enhancement approach to improvement in capstone student's written, oral and presentation skills as part of their final year research project requirements especially for international students, whose first language is not English. Training in these skills have been incorporated into the early stages of the final year research (capstone) project, as an intervention and enhancement program, incorporating a series of intensive seminars and practical applications to provide the students with these capabilities. In this paper, we report on the research question "how does an intensive intervention and enhancement program in an engineering capstone research project effect students' perceptions and their capabilities in communicating their research findings.” Results of student responses showed statistically significant differences between perceptions of local and international students in categories of intervention and enhancement in a tutorial environment for writing, oral communication and presentations. International students perceived the intervention and enhancement process of greater benefit to their engineering future than local students did. Overall, the results from this work are relevant to both international and local students who may be lacking in specialised reporting and English skills.
\end{abstract}

Index Terms-perceptions, final year research project, capstone, enhancement, intervention, communication skills

\section{INTRODUCTION}

Final year projects (also often called capstone projects) for engineering students are critical constituents of an undergraduate engineering program which enriches communication, teamwork and problem solving skills Capstone research project subjects are integrated into the engineering curriculum as a transition or conclusion of the course. Capstone experiences in engineering projects provide the culmination of both theoretical approaches and realistic work practice experiences in the final or senior year of an undergraduate degree. Holdsworth et al [1] argue that final year capstone subjects should be designed to provide students with activities which synthesize the (engineering) discipline specific knowledge, such as communication skills, with the ability to apply this knowledge to real world scenarios. They emphasise that employers put communication skills high on the list of graduate skills along with teamwork and problem solving skills. Importantly, in the most recent ABET criteria for accrediting engineering programs, item (g) of general student outcomes states that students must have "an ability to communicate effectively" [2]. and follows on from a survey from a previous decade, of requirements of industry [3]. ABET requires that engineering courses incorporate teamwork, communication, and project based skills. The final year project capstone courses provide enhancement building these skill sets. The communication skill set particularly important for students from Non-English Speaking Backgrounds and Cultures (NESBC). In a recent survey of how well chemical engineering graduates perceived they were prepared for work in industry, it was found that "there is a clear link between effective communication and technical ability" [4]. It is the continuing need for engineering graduates to have appropriate communication skills in the work environment [1, 3-7,12] and how it is implemented, which is addressed in this work.

\section{A. Background to specific skill requirements}

It is now common in many European and English speaking universities (e.g. in UK, Australia USA [1, 810]) to specially create programs which are taught in English, for students whose first language is not English. Since it is widely accepted that today's engineers are required to deal with a whole range of matters involving scientific, technological and importantly communication issues, they need to be educated with a variety of communication skills embedded and scaffolded throughout the engineering program. The teaching of engineering requires a better understanding of students' English language capabilities to guide their approach to learning, especially in an engineering program $[11,12]$.

Engineering student's communication capabilities in producing reports, posters and giving oral presentations are often below what is expected of them in industry [3, 13, 14]. The engineering final year capstone research project addresses these capabilities, where the communication requirements are recognized as generic skills applicable to all graduate engineers [13, 15-17]. Students themselves have identified specific generic skills which they consider important to their academic training for an outside world $[3,18]$. These skills encompass report writing, oral presentations, together with their overall confidence in English language communication skills, and is particularly important for international students who may not have had the training or experience in English in their country of original education.

In this paper we report on results from a study to enhance student capabilities in producing a number of communication artefacts and the effectiveness of the approach for both local and international students. In this context, we further report on student perceptions and approaches to 
learning various engineering communication skills within a capstone research project as a result of the implementation of an active intervention and enhancement program. Implications and suggestions for employing this instruction technique of enhancement allied to intervention are then discussed. We emphasize the relevance of an intervention and enhancement program incorporating and developing generic communication, writing, reviewing, eposter preparation, and oral presentation skills, by capstone engineering students. Lastly, the paper provides a framework for enhancing communication skill sets, and provides insights from students who have completed the course.

In today's technological world, business and industry leaders are looking for specific skills in entry-level engineers. In a recent study, employers highlighted three skills needed by all workers: teamwork, flexibility, and communication [1, 5]. Result from that study of employers, showed that communication skills of new graduates in engineering are often below the expected level required in industry [4, 5, 7]. At the University of Toledo, studies were conducted which emphasized the importance of senior design capstone projects to build communication and teamwork skills as required by industry [14]. These skills are very important for international students, whose first language is not English and who may not have had the appropriate training or experience. In a qualitative study of four academic departments in a USA university which had a large proportion of international students from NESBC, it was noted that "...a theme common to each (academic) unit was communication difficulties..." [8]. It is well established that the zenith of the project work is the writing of a thesis or report and an oral presentation of the work together with an e-poster to peers and frequently to members of relevant industries or professions [19].

The ability to deliver an effective presentation is prominent on lists of graduate attributes, but the development of effective teaching practices to develop such skills has received only limited attention in the scholarship of teaching and learning [18, 20-24]. Both capstone and graduate students have limited experience of writing for an audience of examiners, or industrial based reviewers, who have definite expectations of just how a report should be structured and delivered both structurally and in an engineering manner [20, 24]. Most students have these difficulties, especially if they are from Non-English Speaking backgrounds or diverse cultures and they are unable to identify with the academic requirements [2124,27]. To enhance the subject delivery and student experience, a feedback process was initiated. This is not dissimilar to a recent study [26], which regarded students feedback as a commonly utilized approach to improve the delivery of a wide range of academic programs.

In most engineering programs in the English- speaking community all students, are expected to write a major thesis in English as part of their capstone research experience in the final year of their engineering studies (both local and international including those from NESBC,). Although communication skills are scaffolded throughout the engineering program, the capstone research subjects require a major written and oral output. The writing, oral presentation, and literature evaluation skills have been incorporated into a formal subject as an intervention and enhancement program into the early stages of the cap- stone research project [22] to provide a systematic approach to the writing process. An intervention and enhancement programs comprising of a series of seminars and active tutorial actions have been developed to provide the students with these capabilities [27-30].

Implementation of activities in reviewing and evaluation of the literature helps the students through the process of comprehensive project proposal writing [31]. Other activities such as delivering an oral presentation and preparing an electronic poster (e-poster) to show their works in one viewing also help students to gain confidence in their communication skills. A similar intervention program concerning writing skills and literature reviewing spread over the whole semester of the final engineering academic year has been implemented at the University of Southern Queensland, where it was found that students' skills in writing and interpreting information were vastly improved[23, 27, 32].

A typical set of student capstone learning objectives and associated outcomes [33], including the ability to:

- Identify a research question (or project problem/objective) and justify the selection of an appropriate and ethically managed research method.

- Produce a written research/project proposal/report/paper and effectively present information in an oral and electronic poster manner Interpret and critically evaluate previously published research in a formal literature.

- Review as part of the project proposal. Describe the characteristic features of common research methods and debate their relative merits.

At our University of Technology, the academic subject matter is delivered with the support of active learning intervention and enhancement in tutorials where they have been initiated in lectures, and incorporate various aspects of e-learning. The academic staff and students have taken the capstone project on-board and it has evolved to a stage where there is increased student satisfaction (students provided their comments about subjects at the end of each semester via University Student Feedback Survey - (SFS).

\section{Structure of the FinAl YeAr Research Project (CAPSTONE) FOCUS}

Historically, there is limited data available on students' perceptions in engineering, especially when it comes to capstone projects [27, 32]. The research data in the present work was drawn from a capstone engineering program at our university (having previously been an Institute of Technology where a research capstone program was not required) and restructured following the 1987-1990, implementation of major national reforms in the Australian higher education sector[34].

The ability to deliver an effective presentation and write an effective report is one of the main generic skills, which students should learn [15, 16, 35, 36].

\section{A. A Framework for Intervention and Enhancement}

The capstone subject is delivered over two semesters. The first semester subject, known as Research Methods, incorporates research, design and development in the form of a project. Engineers Australia statement on Stage 1 Competency Standards for professional Engineers requires that "...Professional Engineers may conduct research 
concerned with advancing the science of engineering and with developing new principles and technologies within a broad engineering discipline. Alternatively, they may contribute to continual improvement in the practice of engineering, and in devising and updating the codes and standards that govern it...” [35, 36]. This subject involves lectures, tutorials, and activities (termed intervention and enhancement) to enhance the student writing, presentations and capabilities to initiate, implement and conduct a major project, together with sessions on relevant statistical research methods.

In the context of subject content, e-learning involved extensive use by students of the Learning Management System (LMS or Blackboard ${ }^{\mathrm{TM}}$ ) for learning, communication and peer group responses [37]. The use of the LMS was not assessed, nor moderated. The students learnt to upload copies of preliminary poster, parts of their writing manuscript, and would then be able to comment on their colleagues' input. In addition, the convener uploaded copies of previous years' poster, reports, and videocapture of past oral presentations. Current students then also had an opportunity to comment and learn from previous work undertaken by students of similar backgrounds in a similar engineering discipline. Again, no assessment was undertaken, with the learning aspect being considered of prime importance. E-learning was used a vehicle for both peer-to-peer learning and that as a depository of information and inter student staff communication activities.

The second semester subject is known as Advanced Research Methods and involves independent learning activities comprising a pure research or development approach, in line with Engineers Australia (EA) competency standards [35, 36]. All activities occur in the "laboratory" - be it experimental, computer/mathematical modelling, or are industry based. Responsibility for the gains in educational knowledge has now shifted to the students, where the capstone project now becomes the focal point for learning.

The course learning objectives have changed over many years but have now settled into the aim as the "identification of the basic principles of academic research and the fundamentals concepts of research", and where appropriate expanded into design and development areas according to individual requirements [38].

In the first semester subject, the lectures deliver only core topics, whereas the tutorials are the working and learning environment. It is here that an intervention and enhancement of communication activities is implemented. At the completion of these activities the students are able to formulate the problem, find the "gap" and develop the project [29]. The structure of the Lecture and Tutorial (intervention and enhancement) sessions is shown in Table 1. All capstone students are required to both write, a comprehensive 15,000 word report and deliver a $15 \mathrm{~min}-$ ute "oral presentation (in English). They are often new to this major report writing and oral presentation in the research and project development environment (although they have in previous years and other subjects written shorter reports and delivered both formal and informal oral presentations).

\section{B. Details of the Tutorial (Intervention and Enhancement) Sessions}

The tutorial/intervention and enhancement sessions are spread over six weeks. Each week has a specific topic and activity assigned to it. The students are informed of the requirements of each activity at the beginning of the overall six tutorial sessions. Each week develops along an agenda, the outline of which is shown in Table II, and specific details elaborated upon in the following sections.

During week one, the tutor explains the stages of a research journey and handed out information which shows the common approaches to research. An outline of the capstone research stages is given in Figure 1, which shows the complex inter-relations amongst all the components of the research journey. Every step involves many intermediary steps and students often stumble, fall, and get back on track, with experience gained in the learning process.

The first stage involves selecting a thesis topic based on theoretical dilemma, industrial topic, academic theme, or personal interest, followed by refining the topic into research questions. The next stage is to design a study which needs to identify specific variables and consideration of the hypotheses. This stage overlaps with an empirical level for validation of the thesis. A further stage involves a theoretical level focusing on interpretation and presenting of data.

The actual research process starts with reviewing the literature and developing research questions and conceptual framework followed by designing a capstone research process, analysing the data, and presenting the findings.

TABLE I.

FRAMEWORK OF THE LECTURE AND TUTORIAL (INTERVENTION AND ENHANCEMENT) SESSIONS

\begin{tabular}{|c|c|c|}
\hline $\begin{array}{c}\text { Week } \\
\text { number }\end{array}$ & Lecture Session & $\begin{array}{l}\text { Tutorial (intervention } \\
\text { and enhancement) } \\
\text { sessions }\end{array}$ \\
\hline 1 & $\begin{array}{l}\text { Introduction, assessment re- } \\
\text { quirement; Project topic selec- } \\
\text { tion; literature resources e.g. } \\
\text { SCOPUSTM }\end{array}$ & $\begin{array}{l}\text { Stages of a research } \\
\text { journey }\end{array}$ \\
\hline 2 & $\begin{array}{l}\text { Project topic selection/; Litera- } \\
\text { ture reviewing }\end{array}$ & $\begin{array}{l}\text { Structure of a research } \\
\text { proposal } \\
\end{array}$ \\
\hline 3 & $\begin{array}{c}\text { Writing up your project proposal; } \\
\text { oral presentations }\end{array}$ & $\begin{array}{c}\text { Finalize the research } \\
\text { topic; literature reviews }\end{array}$ \\
\hline 4 & $\begin{array}{l}\text { Examples and Criticisms of } \\
\text { Reviews/posters/reports }\end{array}$ & $\begin{array}{l}\text { Preliminary literature } \\
\text { review presentation; e- } \\
\text { posters development }\end{array}$ \\
\hline 5 & $\begin{array}{l}\text { Working Week. Electronic } \\
\text { Poster submission }\end{array}$ & Review of past e-posters \\
\hline 6 & $\begin{array}{c}\text { e- Poster presentation, } \\
\text { (A3 portrait pdf) Oral Presenta- } \\
\text { tion }\end{array}$ & $\begin{array}{l}\text { Presentation of initial } \\
\text { research proposal }\end{array}$ \\
\hline
\end{tabular}

TABLE II.

OUTLINE CONTENT OF THE TUTORIAL (INTERVENTION AND ENHANCEMENT) SESSIONS

\begin{tabular}{|c|c|}
\hline Week & $\begin{array}{c}\text { Agenda Content for Tutorial (intervention and } \\
\text { enhancement) sessions }\end{array}$ \\
\hline 1 & Project discussion; stages of a research journey \\
\hline 2 & $\begin{array}{l}\text { Project discussion; structure of proposal; critique of } \\
\text { previous proposal; content importance }\end{array}$ \\
\hline 3 & $\begin{array}{l}\text { How to approach a literature review; periodicals, } \\
\text { conferences, WWW; one page summary of literature } \\
\text { review approach: short presentation to group }\end{array}$ \\
\hline 4 & $\begin{array}{c}\text { Thesis topic and summary of own literature review; } \\
\text { importance and validity of citations }\end{array}$ \\
\hline 5 & Criticize previous e-posters; develop e-posters \\
\hline 6 & $\begin{array}{l}\text { Criticize previous e-reports/thesis; develop report } \\
\text { content. }\end{array}$ \\
\hline
\end{tabular}




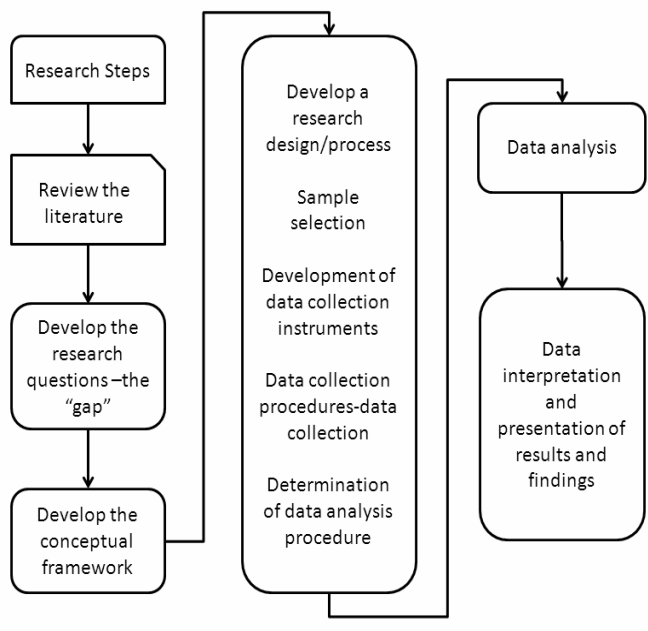

Figure 1. Routes along the capstone research stages.

Students are asked to actively participate in a discussion regarding this approach and provide an example related to their research - either work they have conducted in another subject or have known about which was similar.

In week two, several research proposals which were submitted by students in previous years are distributed during the tutorial time. These are critiqued by all the students. This leads to a discussion of the structure of a research proposal, including various sections such as: executive summary, introduction, background \& literature review, statement of problems, objectives, methodology, milestones \& time schedule, resources \& budget, summary/conclusion, and finally references. Students are asked to read and scan few previous proposals and evaluate these prior proposals based on the structure discussed. As part of the overall oral presentation experience, students have two minutes to present their observations regarding previous proposals. As a corollary the tutor explains his/her evaluation criteria for the previous research proposals and the two approaches are then compared.

By week three, students finalize their research topic. To help students enrich their research, a particular exercise is conducted during the tutorial to show how students should find more relevant articles or sources (with a list of peer reviewed articles), by developing a mind map, similar the approach used by Ashby [39] for papers and reports, and in our case is based on an existing article. Figure 2 shows details of an approach of how students can find the way to enhance their research for appropriate academic articles based on one important reference that they find in an existing article. This approach is employed as a "roadmap" for students to follow in reviewing two academic articles. Two academic articles, one a conference paper and one journal paper, are distributed to the students. They are required to scan those articles and then briefly explain to their peers the structure of papers, the contents and how authors presented their findings. In addition, students present their critique regarding the quality of the references which were used and referred to by the paper authors. Important factors considered by the students are; quality of reference, number of references, age of sources, and types of publications (e.g. industrial reports, conference paper, or journal paper)

For week four, students are required to provide two pages (approximately 500 words) as a preliminary litera-

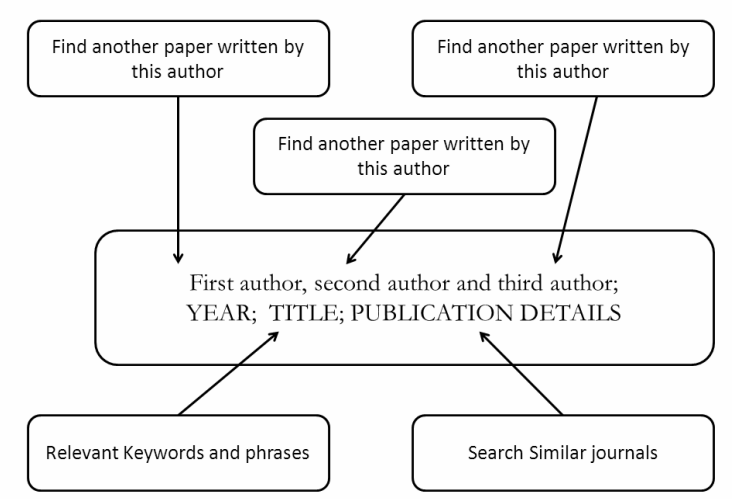

Figure 2. Enhancement of the information literacy resources for the development of the capstone literature review.

ture review of their own capstone topic, and have to include at least five references. Many students commented that this was the first time that they were involved in such an intensive literature search and review procedure. They have to present their findings regarding initial literature review in five minutes during tutorial class in week four. This presentation approach is similar to the "Three Minute Thesis ${ }^{\mathrm{TM}}$ "exercise [40] to explain their research in language appropriate to an intelligent but non-specialist audience on their thesis topic and its significance.

During week five, students work on their e-posters (electronic posters) in the tutorial class. Aspects of communication succinctly and emphatically are discussed and previous samples of e-posters are distributed. The students and the tutor review, critique, and comment on previous eposters submitted over the past few years.

In week six, groups of students present their initial proposal to a panel of judges as well as their peers for five minutes. The proposal includes the kind of work they intend to undertake, involving any: experimental, theoretical, or computational analyses. The judges include the lecturer/convener of the subject, the tutor, visitors, and peers, for overall evaluation. This initial qualitative stage (weeks 1-6) is a precursor to producing a taxonomy of perceptions to be further investigated in an on-going capacity to improve the teaching content approach for final year (capstone) projects and as it is applied to industry [4, $11,12,17]$.

\section{Data Collection AND SuRvey DESIGN METHODOLOGY}

Student response data were gathered through two separate instruments. The first, via a focussed specific capstone questionnaire (SCQ) designed to examine student perceptions of individual components of the first semester capstone subject. The second approach was with a student feedback survey (SFS) developed at our University of Technology to examine student perceptions of general aspects of the subject delivery.

The focused survey (SCQ) was conducted over two years amongst all the capstone students in small tutorial sessions to determine the effectiveness of the active intervention and enhancement specifically in tutorial sessions and generally in lecture sessions for developing communication skills in writing, oral presentation, literature research skills. There was a total of 12 questions asked 
which required a response of 1-5 on a Likert scale (1indicating strongly disagree, to 5- indicating strongly agree). The first seven were concerned with the enhancement program, whilst the final five questions referred to the various aspects of student' perceptions to their approach with fellow students and the information resources provided.

The university-wide survey of students' overall learning perceptions and their feedback (student feedback on subject, SFS) was also undertaken over a period of two years, but contained generic questions applicable to all subjects in which the students were enrolled, and also required a response of 1-5 on a Likert scale. This SFS is a Government initiated approach to improve subject teaching and content. Samples of comments from the SFS are available later in this work.

In total, 140 students of varied backgrounds responded to the survey. From those, 34 students were international (and from non-English speaking backgrounds and cultures) and 106 were local. The data was analysed by SPSS, and independent sample t-tests were conducted to compare the different perceptions between international and local students. The data was analysed to determine both local and international students' perceptions of the benefits of each of teaching and learning activities in the capstone project.

\section{A. Results and Discussion \\ 1) SCQ Survey}

In our work, an initial review of the SCQ data analysis suggested a diversity of responses and perceptions amongst all the students. They differed in their understanding of how to develop and implement both an oral presentations and a written report, especially about the usefulness of receiving assistance in their work.

The survey was paraphrased by two questions concerning the overall final year project, i.e. relating to the requirements of a capstone project, and whether they had undertaken a similar project before. From total of 164 students, there were 140 responses; 95.1\% (134) who declared that they have completed all requirements need for the capstone subject. Out of these 140 responses, only 4 respondents $(2.8 \%)$ claimed that they had undertaken a similar subject before. They commented that it was "useful to do it again".

The results of the SCQ survey are given in Table III and Table IV. The Likert Responses 1 and 2 are grouped as overall disagree and responses 4 and 5 are grouped as overall agree. All the questions are paraphrased by the term "my understanding of the requirements of the Research Project in this subject has improved because of". The questions are grouped according to the student perceptions of their learning in lectures and tutorials and then about the various enhancement activities in the tutorials; incorporating different aspects of writing, and oral presentations, perceptions of using Blackboard ${ }^{\mathrm{TM}} \mathrm{LMS}$, poster presentation and development and information retrieval.

2) Perception of local and international student cohortSCQ

The survey data was analysed to determine both local and international students' perceptions of the benefits of each of teaching and learning activities. An interesting series of phenomena occurred for the international students and their perception of the benefits obtained from
TABLE III.

SCQ SURVEY RESPONSES FOR PERCEIVED BENEFITS OF ATTENDING LECTURES AND TUTORIALS.

\begin{tabular}{|c|c|c|c|c|c|c|}
\hline \multirow{2}{*}{$\begin{array}{c}\text { Concepts: } \\
\text { students } \\
\text { perceived } \\
\text { benefits } \\
\text { from... }\end{array}$} & \multicolumn{2}{|c|}{$\begin{array}{l}\text { International } \\
\text { Students }\end{array}$} & \multicolumn{2}{|c|}{$\begin{array}{l}\text { Local Stu- } \\
\text { dents }\end{array}$} & \multirow{2}{*}{$\begin{array}{c}t \\
\text { (no.) }\end{array}$} & \multirow[t]{2}{*}{$p$} \\
\hline & Mean & S.D. & Mean & S.D. & & \\
\hline $\begin{array}{l}\text {...attending } \\
\text { lectures }\end{array}$ & 3.85 & 0.9 & 3.85 & 0.852 & $\begin{array}{l}0.006 \\
(140)\end{array}$ & 0.995 \\
\hline Result & \multicolumn{6}{|c|}{$\begin{array}{l}\text { No significant difference in means between inter- } \\
\text { national and local students. }\end{array}$} \\
\hline $\begin{array}{l}\text {...attending } \\
\text { tutorials }\end{array}$ & 4.12 & 0.808 & 3.364 & 0.915 & $\begin{array}{l}2.749 \\
(139)\end{array}$ & 0.007 \\
\hline Result & \multicolumn{6}{|c|}{$\begin{array}{c}\text { A significant difference in means between interna- } \\
\text { tional and local students. }\end{array}$} \\
\hline
\end{tabular}

TABLE IV.

SCQ SURVEY RESPONSES FOR PERCEIVED BENEFITS OF INTERVENTION AND ENHANCEMENT OF TUTORIALS.

\begin{tabular}{|c|c|c|c|c|c|c|}
\hline \multirow{2}{*}{$\begin{array}{l}\text { Concepts: } \\
\text { students } \\
\text { perceived } \\
\text { benefits } \\
\text { from... }\end{array}$} & \multicolumn{2}{|c|}{$\begin{array}{l}\text { International } \\
\text { Students }\end{array}$} & \multicolumn{2}{|c|}{$\begin{array}{l}\text { Local Stu- } \\
\text { dents }\end{array}$} & \multirow{2}{*}{$\begin{array}{c}t \\
\text { (no.) }\end{array}$} & \multirow[t]{2}{*}{$p$} \\
\hline & Mean & S.D. & Mean & S.D. & & \\
\hline $\begin{array}{l}\text {..preparing } \\
\text { e-posters }\end{array}$ & 3.88 & 1.066 & 3.46 & 0.844 & $\begin{array}{l}2.388 \\
(137)\end{array}$ & 0.018 \\
\hline $\begin{array}{c}\text {...writing the } \\
\text { e-poster }\end{array}$ & 3.88 & 1.066 & 3.46 & 0.844 & $\begin{array}{l}2.388 \\
(137) \\
\end{array}$ & 0.018 \\
\hline $\begin{array}{c}\text {...attempting } \\
\text { literature } \\
\text { reviews }\end{array}$ & 4.0 & 0.829 & 3.64 & & $\begin{array}{l}2.071 \\
(135)\end{array}$ & 0.040 \\
\hline $\begin{array}{c}\text {..writing the } \\
\text { project } \\
\text { proposal }\end{array}$ & 4.26 & 0.751 & 3.79 & & $\begin{array}{c}3.36 \\
(135)\end{array}$ & 0.001 \\
\hline $\begin{array}{l}\text {..preparation } \\
\text { for oral } \\
\text { presentations }\end{array}$ & 4.09 & 0.753 & 3.31 & & $\begin{array}{l}4.422 \\
(139)\end{array}$ & 0.000 \\
\hline Result & \multicolumn{6}{|c|}{$\begin{array}{c}\text { A significant difference in means between interna- } \\
\text { tional and local students. }\end{array}$} \\
\hline
\end{tabular}

the content and structure of the course. Independent sample t-tests were conducted to compare the benefits between international and local students.

The results of the survey questions asked indicated the following outcomes (however, as some of participants did not answer all questions), the following statistical results for the t-test show slightly different response numbers for each of the seven questions which relate directly to the intervention and enhancement process.

There was no significant difference in means between international and local students; in their perceived gain from lecture attendance

However, there was a significant difference in means between international and local students in their perceived gain from:

- tutorial attendance

- attempting literature reviews in tutorials

- writing the project proposal

- preparing for the e-poster in tutorials

- writing the e-poster in tutorials, and

- preparation for oral presentations in tutorials.

Participation in writing, oral work and, participation in tutorial activities in the tutorial environment, was perceived as being of significance to international students whose first language was not English. Moreover, the local 
students also indicated that the intervention and enhancement program in the tutorials was of importance to their learning the various communication skills. These responses seem to be similar to those obtained for a similar program, for students in both engineering and health sciences [19, 41] and reinforced the results form similar studies of the importance of communication abilities, especially in English [4, 6, 7, 12, 19, 20].

3) Student perceptions of the capstone research project structure-SCQ

All students noted that accessing the Learning Management System and obtaining copies of the lecture material, as well as asking for information from lecturers or fellow students was considered an important learning experience in the final year research (capstone) project. Moreover, it appeared that the lecture material together with the other activities supplemented and contributed to the effectiveness of the in-class tutorial writing sessions.

There appeared to be little influence of any particular one style of teaching (lecture or tutorial), or accessing of information (Blackboard ${ }^{\mathrm{TM}}$ ) or in active participation in the classroom. Even though there was no statistical significance amongst the various activities within the classroom lecture or tutorial, there was a general perception that more was learnt in the tutorial activities of writing documents and preparing electronic written artefacts, ( report and e-poster) than in the lecture environment.

When summing the appropriate responses in their respective categories, the perception of students was that the capstone course in research methods had developed their skills in oral communication and improved their ability to use both written and visual communication skills similar to that found by Harris [41]. Bias-free open-ended comments implied that students could identify and so improve the relationship in their generic competencies and key generic skills [2, 35, 36]. Referring to the specific subject/unit of study, student commented favourably on its continued implementation for future years.

For the case of international students, the data suggested that they perceived a great gain from actively participating in writing and presentations in a small class environment, which have implications for future strategies for teaching

\section{B. Student Feedback Survey (SFS) results}

In addition to determining students' capstone subject perceptions, for the initial year of the introduction of the tutorial intervention and enhancement program allied with the lectures, for the capstone subject in 2009, $89 \%$ of students agreed that, "I have learnt a lot from this unit", and in 2010 a similar response was that $86 \%$ of students agreed.

Further, in 2009: the SFS results showed that $89 \%$ agreed that they "were satisfied" with this unit, whilst in 2010, 97\% agreed to a similar overall satisfaction with the unit (the university phrasing for a subject).

Additionally, for 2009, 82\% agreed that they "were given an opportunity to apply their learning" and this was further reinforced in 2010 where $81 \%$ were of a similar opinion.

Previous years' freeform comments on the Research Methods subjects have been critically constructive and included:
- 'lectures on report preparation would better present earlier in the semester'; and

- 'there should have been some feedback on the literature review in first semester so as to give some insight into how you are doing with the subject'.

When redesigning the capstone subject to its present state, these and many aspects were taken into account and implemented by changing the tutorial activities to cover aspects not covered in detail during lectures. In addition, when comments from the 2010-2011 students' university survey feedback were examined, their response to the feedback question "that the best aspects of this unit were" included:

- 'project proposal writing';

- 'the actual project side of this subject is great. Meeting with my supervisor and discussions about our topic were very useful';

- 'the ability to choose almost any topic you like for your research project'; and

- 'the final research report helps you improve your skills in future'.

From the results of the surveys, it appears that the introduction and implementation, of the intervention and enhancement approach especially in tutorials and to a (lesser extent) lectures has improved student satisfaction in the student learning and content of the capstone research subject. The importance of internet access was not considered to be of the same import as actively implementing the writing requirements.

\section{Students' academic grades outcomes}

To establish the soundness of the findings, analysis of overall final grades data from the first semester capstone project, over a five year period, was gathered from university records to see if the intervention and enhancement process assisted the students to obtain improved academic scores. This form of analysis enhances the content of the research work, eliminates most bias, and attempts to show differences between results, which lead to an overall conclusion $[42,43]$

As shown in the Figure 3, after implementing the active intervention and enhancement process in 2009, the average final mark of students (mean value) increased from 33.5 out of 50 in 2008 to 42.2 out of 50 in 2010 (approx. $21 \%$ increase). In 2011, however, the mean value decreased slightly to 40.9 out of 50 (approximately 3.2\%).

The Standard Deviation of final marks for 2010 and 2011 slightly decreased compared to 2008 and it shows that the range between higher marks and lower marks of students narrowed slightly. The interpretation and use of final grades from the first semester capstone project demonstrated that students improved in marks from the intervention and enhancement program.

\section{Concluding Comments}

The intervention and enhancement program delivered to students in their final year research project (capstone), has shown to be well received by local and international students. . Overall, the multiple modes of implementing intervention and enhancement capabilities were beneficial to both local and international students. The student survey results indicated that the majority of international students found that intensive tutorial activities of most use 


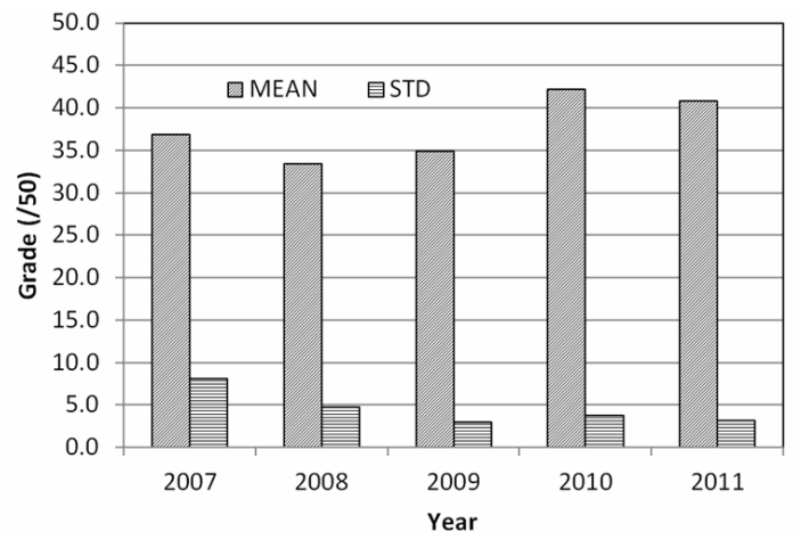

Figure 3. The Mean and Standard Deviation of overall final grades of student in the first semester capstone research subject (2007-2011).

as an adjunct to their learning, and producing necessary outcomes. In addition, the majority of students agreed that their main form of learning was in the actual writing process supplemented by information attained during tutorial attendance, but to a lesser extent lecture attendance. There was an overall improvement in the grades achieved in the literature review, oral presentation and overall report marks

These outcomes have implications for further improvement of the final year research capstone program for both local and international students. A framework for intervening and enhancing engineering student communication skill sets has been provided.

Future stages of the study will include: interviews with the academic staff, observations of the tutorial and student interaction session together with the poster presentations. It is anticipated that a larger project should help inform the definition of exactly what generic skills and competencies can be taught (with appropriate metrics). This work is relevant to both international and local students who may be lacking in specialised English skills.

\section{REFERENCES}

[1] A. Holdsworth, et al., "Developing capstone experiences," 2009 ed. Melbourne Centre for Study of Higher Education, 2009, p. 27.

[2] ABET. (2012, 19 April). Criteria for Accrediting Engineering Programs, $2012 \quad$ - $2013 . \quad$ Available: http://www.abet.org/engineering-criteria-2012-2013/\#

[3] T. E. Pinelli, et al., "Workplace communication skills and the value of communications and information useskills instructionEngineering students' perspectives " presented at the Professional Communication Conference, 1995. IPCC '95 Proceedings. Smooth sailing to the Future., IEEE International, Savannah,, 1995.

[4] R. Martin, et al., "Engineering graduates’ perceptions of how well they were prepared for work in industry," European Journal of Engineering Education, vol. 30, pp. 167-180, 2005. http://dx.doi.org/10.1080/03043790500087571

[5] N. Martin-Young. (2012, 30 May). Communication Skills in the Workplace Employers Talk Back. Available: http://www.nccei.org/newsletter/comskills.html

[6] M. J. Riemer, "English and Communication Skills for the Global Engineer," Global Journal of Engineering Eeducation, vol. 6, pp. 91-100, 2002

[7] J. D. Lang, et al., "Industry Expectations of New Engineers: A Survey to Assist Curriculum Designers," Journal of Engineering Education, vol. 881, pp. 43-51, 1999.

[8] A. G. Trice, "Navigating in a multinational learning community: Academic departments' responses to graduate international students," Journal of Studies in International Education, vol. 1, pp. 62-89, 2005. http://dx.doi.org/10.1177/1028315304271664
[9] Gesellschaft für empirische Studien. (2011, GES Database of Programmes Taught in English. Available: http://www.studyinfo.eu/infopages/Info-Universities.htm

[10] H. P. Jensen and H. Johannesson, "Engineering Courses Taught in English: An Experience from Denmark," European Journal of Engineering Education vol. 20, pp. 19-23, 1995. http://dx.doi.org/10.1080/0304379950200103

[11] J. Tudor, et al., "Perceptions and their influences on approaches to learning," Engineering Education-Journal of the Higher Education Academy Engineering Subject Centre, vol. 5, pp. 69-79, 2010.

[12] P. Sageev and C. J. Romanowski, "A message from recent engineering graduates: results of a survey on technical communication skills," European Journal of Engineering Education, pp. 685-692, 2001.

[13] National Academy of Engineering. (2004, 15th April). The Engineer of 2020: Visions of Engineering in the New Century.

[14] M. Franchetti, et al., "Framework for Implementing Engineering Senior Design Capstone Courses and Design Clinics," Journal of STEM Education, vol. 13, pp. 30-45, 2012.

[15] A. Bradley, "EA Accreditation Criteria Guidelines," Engineers Australia, Canberra2006.

[16] A. Bradley. (2006, 15th April). Engineers Australia Policy on Accreditation of Professional Engineering Programs (PO2 ed.). Available: http://engineersaustralia.org.au/shadomx/apps/fms/fms download.cfm?file_uuid=0B1B282A-EB70-EC35-6B21-BB84E8 F0C8E7\&siteName=ieaust

[17] H. Connor, et al. (2001, 15th April ). An Assessment of Skill Needs in Engineering. Available: http://www.employment-studies.co.uk/ pubs/summary.php?id=dfeesd2

[18] M. Leggett, et al., "Student and staff perception of the importance of generic skills in science," Higher Education Research and Development, vol. 23, pp. 295-312, 2004. http://dx.doi.org/ $10.1080 / 0729436042000235418$

[19] M. Rosse, "What experiences do students value in the development of their oral presentation skills? (" presented at the HESRDA 2009, Darwin, 2009.

[20] J. Bitchener and H. Basturkmen, "Perceptions of the difficulties of postgraduate L2 thesis students writing the discussion section," Journal of English for Academic Purposes, vol. 5, pp. 4-18, 2006.

[21] K. Cadman, "Thesis writing for international students: a question of Identity," English for Specific Purposes, vol. 16, pp. 3-14, 1997.

[22] R. Clerehan and J. Moodie, "A systematic approach to the teaching of writing for supervisors of international students: perspectives from genre theory," presented at the Learning \& Teaching in Higher Education: Advancing International Perspectives(pp73-89) Flinders University, 1997.

[23] S. Cochrane, et al., "An investigation into the application of research strategies in the final-year undergraduate engineering and surveying projects," presented at the Proceedings of the 2009 AaeE Conference, Adelaide, 2009.

[24] T. Wang and L. Y. Li, "Understanding International postgraduate research students' challenges and pedagogical needs in thesis writing " International Journal of Pedagogies and Learning, vol. 4, pp. 88-96, 2008.

[25] SUT, "Policy and Procedure: Research Higher Degrees," Swinburne University of Technology, Hawthorn 2010.

[26] C. S. Nair, et al., "Enhancing the quality of engineering education by utilising student feedback," European Journal of Engineering Education, vol. 36, pp. 3-12, 2011. http://dx.doi.org/10.1080/ $\underline{03043797.2010 .518231}$

[27] S. Goh and H. Ku, "Work in Progress-Intervening to improve the research dissertation of final year engineeirng research projects," presented at the 41st ASEE/IEEE Frontiers in Education Conference, Rapid City, 2011.

[28] K. J. McDermott and J. Machotka, "Enhancing Final Year Project Work in Engineering Programmes," Global Journal of Engineering Education, vol. 10, pp. 181-189, 2006.

[29] R. K. Prud'Homme, "Senior Thesis Research at Princeton," Chemical Engineering Education, vol. 15, pp. 130-132, 1981. 
PAPER

INTERVENTION IN ENGINEERING StUdENTS’ FINAL YEAR CAPSTONE RESEARCH PROJECTS TO ENHANCE THEIR WRITTEN, ORAL AND PRESENTATION SKILLS

[30] A. S. Blicblau and K. Dini, "Students' perceptions of an active learning approach to capstone projects," Global Journal of Engineering Education, vol. 14, pp. 14-19, 2012.

[31] E. Weinstein, "Using technical articles to teach technical report writing," Technical Writing Teacher, vol. 14, pp. 151-157, 1987.

[32] H. Ku and S. Goh, "Final year engineering projects in Australia," European Journal of Engineering Education, vol. 35, pp. 161-173, 2010. http://dx.doi.org/10.1080/03043790903497336

[33] A. Thambyah, "On the design of learning outcomes for the undergraduate engineer's final year project', European Journal of Engineering Education," European Journal of Engineering Education, vol. 36, pp. 35-36, 2011. http://dx.doi.org/10.1080/ $\underline{03043797.2010 .528559}$

[34] G. Harman, Ed., Implementing comprehensive national higher education reforms: the Australian reforms of Education Minister John Dawkins, 1987-1990. Dordrecht: Springer, 2007.

[35] EA. (2011, 22 April 2012). Engineers australia National generic stage 1 competency standards Available: http://www.engineersaustralia.org.au/sites/default/files/shado/Edu cation/Program\%20Accreditation/110309\%20Foreword\%20to\%2 0Stage\%201\%20Standards.pdf

[36] EA. (2011, 22 April 2012). Stage 1 Competency Standard for Professional Engineer. Available: http://www.engineersaustralia.org.au/sites/default/files/shado/Edu cation/Program\%20Accreditation/110318\%20Stage\%201\%20Prof essional\%20Engineer.pdf

[37] A. S. Blicblau, "Interactive capstone portfolios," International Journal of Engineering Education vol. 24, pp. 1078-1083, 2008.
[38] SUT-FEIS. (2012, 30 May). Advanced Research Project Unit Code: HES5103 Available: http://courses.swinburne.edu.au/ subjects/Advanced-Research-Project--HES5103/local

[39] M. Ashby. (2006, 15th April ). How to Write a Paper (6th ed. ed.). Available: http://www.grantadesign.com/userarea/teachingresou rce/writeapaper.htm

[40] University of Queensland. (2011, 19th April ). The Three Minute Thesis (3MT) Available: http://www.uq.edu.au/grad-school/threeminute-thesis

[41] L. Harris, et al., "Prioritizing Communication: Theory, Practice and the Student Experience in the Bachelor of Health Science (Showcase)," presented at the HESRDA 2009, Darwin, 2009.

[42] S. Mathison, " Why triangulate? ," Educational Researcher, vol. 17, pp. 13-17, 1988

[43] O. Ghrayeb, et al., "Art of triangulation: an effective assessment validation strategy," Global Journal of Engineering Education, vol. 13, pp. 96-101, 2011.

\section{AUTHORS}

A.S.Blicblau is a senior lecturer in the Faculty of Engineering and Industrial Sciences at with Swinburne University of Technology, Hawthorn Australia 3122 (e-mail: ablicblau@swin.edu.au).

K.Dini, is a tutor in the Faculty of Engineering and Industrial Sciences with Swinburne University of Technology, Hawthorn Australia 3122 (kdini@swin.edu.au).

Received May 8, 2012. Published as resubmitted by the authors 24 June 2012. 